\title{
HISTÓRIA E HISTORIOGRAFIA DA SAÚDE E DAS DOENÇAS NA PARAÍBA
}

\section{HISTORY AND HISTORIOGRAPHY OF HEALTH AND DISEASES IN PARAÍBA}

\author{
Azemar dos Santos Soares Júnior* \\ Universidade Federal do Rio Grande do Norte - UFRN \\ https://orcid.org/0000-0003-0015-415X \\ azemarsoares@,hotmail.com
}

\begin{abstract}
RESUMO: Esse texto tem por objetivo discutir a produção historiográfica sobre o campo da história da saúde e das doenças na Paraíba. Para tanto, utilizei a categoria de geração para pensar os primeiros escritores (médicos e jornalistas) sobre o tema, atrelados a uma história tradicional, e no segundo momento, as produções acadêmicas a nível de pós-graduação. As fontes problematizadas são revistas especializadas, livros, dissertações e teses. Conclui-se que existe um considerável número de pesquisas no campo da história da saúde e das doenças que contribui para o entendimento do processo de construção social da doença.
\end{abstract}

PALAVRAS-CHAVE: História da saúde e das doenças, Historiografia, Paraíba.

ABSTRACT: This text aims to discuss historiographic production on the field of the history of health and diseases in Paraíba. Therefore, I used the generation category to think of the first writers (doctors and journalists) on the subject, linked to a traditional history, and at the second moment, academic productions at the postgraduate level. The problematized sources are specialized journals, books, dissertations and theses. It is concluded that there is a considerable number of research in the field of health history and diseases that contributes to the understanding of the process of social construction of the disease.

KEYWORDS: History of health and diseases, Historiography, Paraíba.

Doutorado em Educação (PPGE/UFPB). Pós-Doutorado em História pela Universidade Federal de Campina Grande. Atualmente é Professor Adjunto do Departamento de Práticas Educacionais e Currículo, na área de Didática e Ensino de História da Universidade Federal do Rio Grande do Norte (DPEC/UFRN), Campus Natal. É professor credenciado no Programa de Pós-Graduação em Educação da Universidade Federal do Rio Grande do Norte (PPGEd/UFRN) e no Programa de Pós-Graduação em História da Universidade Federal de Campina Grande (PPGH/UFCG). Sócio efetivo do Instituto Histórico e Geográfico do Rio Grande do Norte (IHGRN). 


\section{INTRODUÇÃO}

Dentre as obras sobre o tema da História da Saúde e das Doenças na Paraíba, é possível enumerar dois grupos de intelectuais que se dedicaram à produção historiográfica sobre o tema. São grupos de pesquisadores marcados pela forma de produção de saber atrelada a seu lugar social, ou seja, escritores que confeccionaram em forma de texto, experiências e dizeres vinculados à instituição intelectual a que pertenciam. Para melhor entender a opção de pensar esses dois grupos enquanto gerações, recorri aos escritos de Jean-François Sirinelli (2001) que defendeu a existência de modelos de intelectuais que se distinguem por suas gerações: a primeira, de forma mais abrangente, "incluindo todos os sujeitos envolvidos com atividades laborais associadas ao escrito, tanto como criadores, como na qualidade de mediadores" (SIRINELLI, 2001, p. 9), nesse caso, identificados com aqueles que escreveram textos sobre o tema apenas por se considerarem intelectuais autorizados pelas instituições de saber ao qual estavam associados, não se dedicando apenas ao campo da saúde e da doença, mas a toda sorte de assuntos; o segundo grupo, "para além de [ser uma] geração modelada pelo acontecimento, há ainda o da auto representação e da autoproclamação: o sentimento de pertencer ou ter pertencido" (PINHEIRO, 2019, p. 4).

Embora um dos critérios apontados pelo historiador francês seja o de pertencimento, ou seja, aqueles historiadores que se classificam e se rotulam como pertencentes a um determinado campo, nem sempre é possível encontrar nos textos afirmações que possam alinhavar os pesquisadores com essa identidade, tampouco, sua autodeclaração no currículo lattes. Portanto, tomei a liberdade de classificar os pesquisadores da segunda geração como historiadores da saúde e das doenças pelo fato de terem construído um texto acadêmico a nível de pós-graduação, dentre as diversas possibilidades temáticas que o campo oferece.

Nesse sentido, esse texto está organizado de forma a discutir a produção dita historiográfica das duas gerações de escritores do campo da história da saúde e das doenças. Para tanto, foi preciso realizar o levantamento das principais obras que tratam do tema: os artigos publicados na Revista do Instituto Histórico e Geográfico da Paraíba e na Revista Medicina, os Anais da Semana Médica publicado em 1927, os livros A Paraíba e seus Problemas (1923) de José Américo de Almeida, Medicina na Paraíba (1945) de Oscar de Castro, As raízes das ciências da saúde na Paraíba (1979) de Humberto Nóbrega, A velha Paraíba nas páginas dos jornais (1999) de Wellington Aguiar, o Dicionário biográfico dos médicos da Paraíba (2014) dos médicos José Medeiros e José Lucas, além das dissertações e teses defendidas entre os anos 
de 1999 e 2020 e que foram classificadas como pesquisas no campo da saúde e das doenças.

\section{A PRIMEIRA GERAÇÃO}

A primeira geração ${ }^{1}$ era formada essencialmente por médicos e intelectuais vinculados ao Instituto Histórico e Geográfico da Paraíba (IHGP). Portanto, essa produção não é composta de textos acadêmicos e que na maioria das vezes, são utilizados como fontes históricas. Nessas obras, é possível encontrar quase que exclusivamente a transcrição de documentos históricos delicadamente selecionados com o interesse de assegurar fatos e personagens que "muito contribuíram" para a saúde na Paraíba. A maioria desses textos são marcados por um saudosismo responsável por edificar a imagem dos médicos e políticos como aqueles que foram capazes de "salvar" a sociedade das doenças e dos surtos epidêmicos, bem como, registrar os feitos em defesa de homens e mulheres contra os males que constantemente atacavam seus corpos. Falas e discursos de presidentes de Província/Estado direcionadas à Assembleia Legislativa, relatórios da Saúde Pública produzidos pelos chefes da higiene e do porto, descrições das condições sanitárias das cidades, medidas políticas tomadas pelos líderes de estado em tempos de epidemias, perfis de médicos que atuaram na geografia paraibana, publicidade de medicamentos que prometiam a cura do corpo contra as enfermidades, dentre outros, são constantemente encontradas nesses escritos.

Algumas dessas obras tornaram-se leitura quase que obrigatória aos investigadores do campo da história da saúde e das doenças, sobretudo, porque alguns desses documentos se perderam ou estão trancados a sete chaves nas estantes empoeiradas dos "guardiões da memória”. Para melhor apresentar essas obras, vejamos o quadro abaixo:

Quadro 1. Publicações pertencentes a primeira geração de intelectuais que escreveram sobre o tema da saúde e das doenças na Paraíba

\begin{tabular}{|c|c|c|c|}
\hline & TíTULO & AUTOR & ANO \\
\hline $\mathbf{0 1}$ & O cholera-morbus na Paraíba & Irineu Pinto & 1910 \\
\hline $\mathbf{0 2}$ & $\begin{array}{c}\text { Algumas páginas (Subsídios para a história da } \\
\text { hygiene pública na Parahyba) }\end{array}$ & Coriolando de Medeiros & 1911 \\
\hline
\end{tabular}

1 Como afirmo ao longo do texto, nenhum desses escritores tinha formação acadêmica em História, embora se colocassem na condição de "Guardiões da história", devido a sua vinculação com IHGP. Tomo a liberdade de classifica-los como intelectuais que produziram textos sobre o tema em tela, mesmo sabendo que a época não existia o campo da História da Saúde e das Doenças, este criado pelos idos dos anos 2000 . 


\begin{tabular}{|c|c|c|c|}
\hline 03 & A nossa hygiene. Considerações gerais & Flávio Maroja & 1911 \\
\hline 04 & A Paraíba e seus Problemas & José Américo de Almeida & 1923 \\
\hline 05 & Semana Médica & $\begin{array}{l}\text { Sociedade de Medicina e Cirurgia } \\
\text { da Paraíba }\end{array}$ & 1927 \\
\hline 06 & $\begin{array}{c}\text { Subsídios a história da medicina na Parahyba: } \\
\text { corrida de diagnósticos }\end{array}$ & Oscar Oliveira de Castro & 1936 \\
\hline 07 & $\begin{array}{c}\text { Subsídios a história da medicina na Parahyba: o } \\
\text { caso Thomaz Camboia }\end{array}$ & Oscar Oliv & 1936 \\
\hline 08 & $\begin{array}{c}\text { Subsídios a história da medicina na Parahyba: um } \\
\text { caso esporádico }\end{array}$ & Oscar Oliveira & 1937 \\
\hline 09 & Medicina na Paraíba & Oscar Oliv & 1945 \\
\hline 10 & A epidemia de cólera morbo na Paraíba em 1856 & Heronides Alve & 1959 \\
\hline 11 & $\begin{array}{l}\text { Medicina, doenças e médicos nos primeiros anos da } \\
\text { Paraíba }\end{array}$ & Heronides Alves Coelho Filho & 1971 \\
\hline 12 & As raízes das ciências da saúde na Paraíba & Humberto Nóbrega & 1979 \\
\hline 13 & A velha Paraíba nas páginas dos jornais & Wellington Aguiar & 1999 \\
\hline 14 & Dicionário biográfico dos médicos da Paraíba & $\begin{array}{l}\text { José Eymard Medeiros } \\
\text { José Morais Lucas }\end{array}$ & 2014 \\
\hline
\end{tabular}

Fonte: Quadro elaborado pelo autor a partir do levantamento de obras sobre o tema da história da saúde e das doenças na Paraíba (2021).

Os textos acima estão publicados em forma de artigos, em revistas produzidas pelo Instituto Histórico e Geográfico da Paraíba (IGHP) ou pela Sociedade de Medicina e Cirurgia da Paraíba (SMCPB); ou em formato de livros.

Os artigos são textos mais curtos e que possuem em torno de oito a quinze páginas. Esses escritos em forma de artigo, foram publicados nos periódicos atrelados às sociedades responsáveis por reunir intelectuais que se incumbiam da missão de produzir e circular saberes para os seus pares. A Revista do Instituto Histórico e Geográfico da Paraíba, por exemplo, ao longo de todas as suas edições publicou quatro textos que se configuram enquanto contribuição (ou fonte histórica?) para a história da saúde e das doenças: $O$ cholera-morbus na Paraíba de Irineu Pinto, publicado na segunda edição da revista, trata da primeira epidemia de cólera ocorrida na Paraíba no ano de 1856. A princípio, o autor apresenta a origem asiática da enfermidade e em seguida descreve como a doença foi galgando territórios Brasil afora, até chegar à Paraíba. Esse escrito é alinhavado às narrativas políticas dos presidentes da época que visavam fazer saber as principais medidas tomadas pelo governo provincial. Notoriamente, há uma reprodução da fala do então chefe do governo à época, sem que se faça menção ao documento. Outra característica pertinente ao artigo, é a referência a colegas que contribuíram com informações sobre a epidemia, a exemplo de Flávio Maroja que, por ser médico e chefe da saúde pública, tinha o conhecimento acerca da documentação sobre as epidemias ocorridas na Província. Há ainda a indicação das medidas consideradas higiênicas e de combate à pandemia, como a ação de câmaras municipais que criaram códigos de posturas, a atuação dos poucos 
médicos que trabalhavam clinicando, o envio de socorros para as cidades e vilas afetadas, os dados estatísticos de mortos, dentre outros. Como um texto de caráter metódico, não é possível verificar uma análise das fontes, apenas a construção de uma narrativa.

Na terceira edição da Revista do IHGP, de 1911, foram publicados dois textos na área: Algumas páginas (Subsídios para a história da bygiene pública na Parabyba), de autoria de Coriolando de Medeiros e A nossa hygiene. Considerações gerais escrito por Flávio Maroja. Em Algumas páginas..., o autor afirmou que a Paraíba sempre foi "reputada como terra salubre e de clima agradável" e que das doenças endêmicas, somente "as febres palustres e a varíola são genuinamente locais". Esse foi o ponto de partida para o autor descrever os constantes surtos de varíola que se tinha registro desde o período colonial brasileiro. Os parágrafos seguintes são dedicados à descrição das péssimas condições de higiene e à constituição de leis municipais ao longo do século XIX, que normatizavam a salubridade pública e contratavam profissionais médicos para atuar no cuidado dos enfermos. Dentre tais medidas, o autor dedica algumas páginas à descrição da vacinação dita obrigatória nas localidades do interior da Província. Em seguida, Coriolando de Medeiros dedica alguns parágrafos ao "infortúnio" da epidemia de cólera ocorrida em meados do oitocentos e como a população foi pega de surpresa pela doença, exigindo ação enérgica por parte dos poderes públicos e reivindicando uma maior atenção às condições de higiene. A maior parte deste documento é dedicado à descrição da ciranda presidencial da Província da Paraíba e à exaltação aos médicos que atuaram ao longo da epidemia colérica. Esses últimos foram responsáveis por produzir relatórios médicos minuciosos, nos quais, algumas de suas partes foram transcritas e publicadas no texto. Um dos relatos mais utilizados foi o do médico Abdon Felinto Milanez, em tempos de febre amarela, responsável por denunciar que os principais problemas sanitários eram a localização e construção do cemitério público, o desprezo com os princípios de higiene na construção do matadouro, a falta de asseio de ruas e praças, a inconstância das estações do ano e a estagnação das águas. $\mathrm{O}$ autor recorreu à documentação para construir um texto denunciativo sobre as condições sanitárias da Paraíba no começo do vigésimo século, a qual considerou "criminosamente desprezado pelos nossos antepassados" (MEDEIROS, 1911, p. 123).

Em A nossa hygiene..., Flávio Maroja prometeu realizar um "estudo das condições higiênicas da capital". Em tom denunciativo, o texto chama atenção para anotações cotidianas das condições de salubridade de uma cidade que, nas palavras do autor, muito precisava ser feito para atingir os termos da higiene moderna, ou seja, "se evidencia a 
necessidade urgente da organização do serviço de hygiene desta capital, até agora desconhecedora de seu coeficiente de natalidade e mortalidade à falta de uma estatística demógrafo-sanitária" (MAROJA, 1911, p. 432). Apesar do anúncio discursivo, o autor rasgou elogios e não poupou o governo de boas adjetivações: "Não podem deixar de ser levado em grande conta os serviços iniciados pela ilustre e operosa Presidência do Estado e pela digna Prefeitura da capital, no sentido de imprimirem nova feição esthetica a esta cidade" (MAROJA, 1911, p. 433. Grifos meus). Enquanto médico, defendia que o modelo de serviço público sanitário adotado pelo governo deveria ser o de "hygiene defensiva" que consistia em assegurar saneamento básico, profilaxia das moléstias transmissíveis, criação de delegacias de higiene nos municípios equipadas de funcionários preparados. A ordem de seu discurso parecia orientar os chefes de governo à "correta" formar de conduzir a higiene na Paraíba, para isso, recorreu à apresentação de dados positivos dos estados vizinhos de Pernambuco e Ceará, além de sempre que possível, acentuar uma denúncia: "A hygiene pública da Parahyba, guardando a simplicidade de sua primitiva organização, revelou apenas sua existência por ter provido o cargo de inspector, função que é exercida por um facultativo competente e trabalhador" (MAROJA, 1911, p. 434).

Em seguida, o autor transcreveu uma publicação que circulou na edição do jornal A União, intitulado A Hygiene, na qual reafirma a modéstia de uma inspetoria atrasada em relação à higiene moderna e à reivindicação de ações coerentes com os tempos vividos. Por fim, dedica as últimas linhas para falar sobre a "febre typhoide", que acreditava ser transmitida por resíduos fecais, investindo seus enunciados em convencer o leitor e os órgãos competentes na adoção de uma educação sanitária de cuidado com as fezes, com o lixo e com o esgoto, como sendo o problema que "mais prende a atenção do hygienista". Esse texto em específico mais se assemelha a uma crônica, na qual os aspectos cotidianos da época são tratados em tons denunciativos. Para tanto, Flávio Maroja parece ter se apropriado do recurso "morde e assopra": faz acusações ao governo e aos governantes, na mesma medida em que utiliza adjetivações respeitosas como "digna" e "ilustre".

O quarto e último texto sobre o assunto da saúde e doença, contido na Revista IHGP, é de autoria de Heronides Alves Coelho Filho, intitulado de Medicina, doenças e médicos nos primeiros anos da Paraíba e publicado no ano de 1971. O artigo foi fruto de uma palestra proferida pelo intelectual, na qual o tema central são as questões vinculadas à saúde no início da colonização da Paraíba. Dentre os quatro textos sobre o tema, esse é o que apresenta um diálogo e referência a outros documentos como $A$ Carta de Pero Vaz de Caminha, os Diálogos das Grandezas do Brasil, e obras como Tratado da terra e gente do Brasil de 
Fernão Cardim, a História natural e médica da Índia Ocidental de Guilherme Piso, a História da Provincia da Paraíba de Maximiano Lopes Machado, dentre outros. Dentre as doenças apontadas no texto, o autor cita a troca de enfermidades pautada na varíola e no sarampo trazidos pelos europeus para os indígenas, e a sífilis e a bouba retribuída pelos indígenas aos europeus. Conta a partir da descrição de documentos que a sífilis havia sido levada da América para Europa provocando no corpo dos homens "repugnantes manifestações cutâneas de início, predominantemente visceral” (COELHO FILHO, 1971, p. 180), mas, que muito mais grave fora a varíola e o sarampo em terras ameríndias, dizimando milhares de nativos. Heronides Coelho Filho faz a defesa do fascínio da História da Medicina nos primeiros anos da chegada dos europeus. $\mathrm{Na}$ verdade, não acredito se tratar de uma História da Medicina, mas de uma descrição histórica das epidemias sem necessariamente a existência de profissionais médicos ou mesmo de medicamentos capazes de curar os corpos infectados: “[...] a absoluta ausência de contribuições médicas, sobretudo, agravava esses problemas” (COELHO FILHO, 1971, p. 181). Essa é a história de uma colonização cruel, responsável por distribuir armas biológicas capazes de ceifar a vida de uma população inteira: “[...] mais que a força das armas, deve-se as epidemias a vitória dos castelhanos sobre os impérios Maias e Astecas" (COELHO FILHO, 1971, p. 181). Ao tratar de forma mais específica da Paraíba, Heronides Coelho Filho ressalta os constantes ataques de varíola à população indígena desde o período da colonização, recuperando um pouco da origem da doença e sua chegada ao Brasil, e em seguida, apresentando dados de mortos pela enfermidade em algumas localidades do Nordeste do Brasil. As descrições do dia a dia dos indígenas são apontadas ao longo do texto, para mostrar ao leitor o "exato momento" em que o cotidiano era violentado pela desventura das bexigas. Vejamos a narrativa:

O índio no meio de uma pescaria, ou descansando dos labores da guerra numa rede, sentia de repente violento calafrio e subitâneo, como relâmpago em céu sereno, atinge-lhe violenta cefaleia. Logo em seguida a febre, febre alta, cada vez mais alta. Pouco depois cobria-lhe a pele extenso exantema, logo transformando em pústulas, de mau cheiro insuportável. De mistura com o pús, fétido e repelente, corria nas mulheres o sangue menstrual pois, fato interessante, pois nestas o aparecimento da doença determina amiúde o aparecimento da menstruação. E com o pús e o sangue, o edema e o delírio. E a coceira. Prurido intenso, insuportável, infernal. E mais uma vez a febre. E ainda e sempre o delírio. Loucos, jogavam-se na água para refrescar, ou nas fogueiras para aliviar. Singular clamor elevava-se aos céus. 
A narrativa não possui a indicação de que foi transcrita de algum documento. $O$ texto aparece como construção do autor, acredito que a partir das referências sobre a vida dos indígenas associadas ao saber médico acerca do desenvolvimento da doença. De qualquer forma, a narrativa apresentada é capaz de fazer leitor tapar o nariz e os olhos só de imaginar o mau cheiro e o corpo pipocando em pústulas. Além da varíola, o autor apresenta uma lista de enfermidades que acometeram os paraibanos nos primeiros cinquenta anos da colonização: apendicite, bouba, banzo, bicho de pé, câmaras ou fleumas, diarreia, desvitaminose, febres, estilicídio, mal das pedras, mordexim, maculo, paludismo, postermas e chagas, piolho, sarampo e sífilis. Anunciou que o tratamento dessas doenças era feito com produtos naturais receitados por pajés e curandeiros, como também por médicos, embora ao longo do seu texto afirme que a documentação oficial trocada com a coroa portuguesa só faça referência à presença desse profissional na Bahia. Mas, valendo-se de uma passagem do Diálogos das Granderas do Brasil, em que "na Paraíba testemunha o autor dos Diálogos, os nossos portugueses que habitam por estas partes... se curam com médicos, barbeiros e cirurgiões portugueses" (COELHO FILHO, 1971, p. 190) passou a defender que o Ambrósio Fernandes Brandão, autor do "Diálogos das Grandezas do Brasil" adquiriu a ciência médica antes de vir para a Paraíba, pois só um médico poderia “[...] se assenhorar de tão vasta e rica bibliografia especializada [...] recenseando 13 condições mórbidas, descrevendo os sintomas e terapêutica, ter diagnosticado e tratado o maculo e a descrever a cura do mal dos bichos" (COELHO FILHO, 1971, p. 194-195). O autor percebe na literatura o indício da existência de um possível profissional médico atuando na Paraíba colonial.

Dentre os textos publicados na Revista do IHGP, o Medicina, doenças e médicos nos primeiros anos da Paraíba é o que mais se afasta daqueles publicados no início do século XX, caracterizado por exaltar fatos e heróis, transcrever documentos ou assumir o formato de crônica denunciativa. O texto de Heronides Coelho Filho, embora ainda esteja dentro de uma tradição positivista marcada pela narrativa, pela construção da verdade e pela ausência de análise documental, ele se diferencia dos demais textos contidos no periódico sobre o tema da saúde e doença, pelo diálogo com outras obras e autores.

Ainda na toada de artigos, é importante destacar os Subsídios á bistória da medicina na Parabyba, publicados nas edições de 1936 e 1937, na Revista Medicina, por Oscar Oliveira de Castro. Esses textos pareceram funcionar como um ensaio que gestaria o livro Medicina na Paraíba, publicado nove anos depois, e que falarei mais adiante. Os artigos são uma espécie de trilogia que contribuiria para a história da medicina paraibana: o primeiro publicado na 
edição do primeiro semestre de 1936, intitulado Subsidios á história da medicina na Parabyba: o caso Thomaz Camboia, no qual o autor apresenta o infortúnio do enfermeiro que teve a perna avolumada por um tumor e que precisou ser retirado, através de um procedimento cirúrgico meticulosamente estudado pelos médicos Cruz Cordeiro e Ernesto Feliciano. O artigo é marcado pela descrição das cenas, levando o leitor a imaginar os acontecimentos narrados. Os personagens são apresentados e adjetivados com as melhores alcunhas e elogios. Além do caso clínico da retirada de um tumor crescido em um dos membros inferiores de Thomaz Camboia, a trama é enredada pelo lugar político-social dos médicos e pela intenção de sensibilizar conservadores e liberais com a situação do enfermeiro que, mesmo curado, enfrenta a desventura da morte de sua noiva que contraiu algum mal súbito e não diagnosticado, ao ir assistir a operação de seu prometido.

O segundo artigo, publicado na edição do segundo semestre de 1936, chamado de Subsídios á história da medicina: corrida de diagnósticos, conta a história do coronel Aranha Chacon, que "há mais de seis meses, estava com febre alta, intermitências que desafiavam o tino clínico e a cultura de seu médico, parente e amigo, o Dr. Abdon Felinto Milanez" (CASTRO, 1936, p. 24). Com a constante piora do quadro clínico, outros médicos foram convocados para emitir pareceres: os doutores José Lopes da Silva Júnior e Cruz Cordeiro. As anotações indicavam afastar o diagnóstico de beribéri, febre miasmática e confirmar o laudo de "febre syntomática de lesões do aparelho genito urinário [...] acompanhadas de irritação do sistema nervoso e repleção dos vasos hemorrhoidarios” (CASTRO, 1936, p. 25). A narrativa é associada à guerra discursiva travadas entre os jornais $A$ Opinião e $O$ Libertador, naquele ano de 1887. De um lado, um jornal $A$ Opinião publicava os diagnósticos do Dr. José Lopes, do outro, as receitas e os maldizeres do Dr. Abdon Milanez ganhavam as páginas d'O Libertador. Os ataques e contra-ataques dos médicos acabaram por não resolver o problema do doente que buscou ajuda clínica na cidade do Recife, onde recebeu o diagnóstico de "beri-beri, complicado de sofrimentos na próstata, agravado por princípios tóxicos de tintas" (CASTRO, 1936, p. 27), fato que fez ambos os médicos a saírem às ruas comemorando e anunciando que era deles o diagnóstico correto. Ao final do texto, o autor escreveu que a narrativa estava no "livro a sahir, edição Medicina", ou seja, era uma história que iria compor o quadro de narrativas contidas no livro Medicina na Paraíba. A construção desse curto artigo é marcada pela transcrição e apropriação de notícias jornalísticas do século XIX, responsável por revelar que as discordâncias entre os médicos paraibanos não eram apenas políticas, mas também de diagnósticos. 
Já no terceiro artigo publicado na edição de 1937, sob o título de Subsidios á bistória da medicina na Parabyba: um caso esporádico, o tema central é o cólera morbo. De início, Oscar de Castro relata rapidamente o infortúnio das duas epidemias da doença ocorridas respectivamente em 1956 e 1961. Afirmou que apesar de passada a epidemia, vez por outra batia à porta da Paraíba um navio portando um enfermo de cólera, que era rapidamente inspecionado pelos médicos, enquanto funcionários públicos. Esse fato foi exemplificado através do episódio da chegada no Tocantins, um vapor da Companhia Brasileira que havia aportado em Cabedelo. Essa inspeção foi realizada pelo Comendador Poggi, que ao retornar à capital da Província recebeu a notícia de um doente de cólera na Estrada do Carro, localizada no centro da cidade. Ao chegar ao local em que o enfermo se encontrava, realizou o diagnóstico junto aos médicos Cruz Cordeiro e Abdon Milanez. A narrativa de Oscar de Castro é alegorizada com a inquietação: "Quem não tinha medo da maldita doença? Até a velha Damásia, que com elle vivia tinha medo de entrar no quarto infectado" (CASTRO, 1937, p. 38). Na verdade, essa questão foi um recurso discursivo para anunciar o "heroísmo" dos médicos: "[...] isso competia aos médicos. Elles é que tinham o dever de se expor ao contágio. Que duro sacrifício! Pegar a doença para elles era doloroso, mas nada tinham que fazer. E quantos médicos e sacerdotes foram vítimas no primeiro e segundo cholera" (CASTRO, 1937, p. 37). Por fim, passou a apresentar os sintomas apresentados pelo paciente, o Sr. Ignácio Ferreira, como olhos profundamente encovados, face amarelada e descomposta, suor frio e viscoso, pulso pequeno e contraído, quebrantamento das forças, voz caída e sede intensa, terríveis cólicas, diarreia, vômito e câimbras. Apesar do diagnóstico, o autor alegou ser aquele um caso esporádico ocorrido no ano de 1867, justificando o subtítulo da publicação. O paciente foi curado e medidas de desinfecção foram adotadas, conforme o discurso proferido por Oscar de Castro. Dos três artigos, o último é o único no qual nenhuma referência à documentação é feita. A narrativa é escrita como se o autor fosse partícipe da visita médica ao doente. Não é dito ao leitor de qual fonte histórica estava sendo transcrita.

Além dos três primeiros artigos que subsidiam essa dita história das doenças, na edição de número 19, publicada no ano de 1959, foi possível encontrar o artigo intitulado A epidemia do cólera morbo na Paraíba no ano de 1856, de autoria do médico Heronides Coelho Filho, anunciando que a "Paraíba sempre pagou um enorme tributo as epidemias". O escrito tratava sobre a "besta do Ganges", o nascimento da fera indiana, os caminhos percorridos mundo afora até adentrar pelas portas dos fundos da Paraíba. O texto apresenta dados quantitativos sobre os mortos devorados pela besta, e a afirmação de que 
"de todas as epidemias dos primeiros 60 anos do século XIX, nenhuma foi mais cruel para com esta terra que o cólera morbo" (COELHO FILHO, 1959, p. 34).

Esses artigos publicados na Revista Medicina são aqueles aos quais se pode atribuir um teor histórico a partir de seu título. Foram escritos com a função de dar "subsídio" à história da medicina na Paraíba, de tornar-se fonte a ser consultada na hora de estudar sobre o tema. As análises são quase inexistentes, ficando apenas a apresentação do documento em forma de narrativa, que por vezes, buscou atribuir um tom de heró́smo aos médicos oitocentistas que como "bravos guerreiros" faziam de sua profissão um sacerdócio, sendo capazes, inclusive, de adoecer e morrer, na tentativa de curar.

Se os artigos publicados em revistas foram os primeiros escritos que podem ser caracterizados como pertencentes a uma primeira geração de produção dita histórica sobre o tema da saúde e das doenças na Paraíba, os livros passaram a figurar espaço de mesma importância na hora de contar essa história próxima aos moldes de uma teoria Ranqueana, na qual cada fato histórico é único e sem possibilidade de repetição. Uma história objetiva em que as subjetividades devem ser afastadas para assim ser atribuído um caráter de verdade e de cientificidade. Não estou aqui afirmando que esses autores eram historiadores pois, em sua maioria, eram médicos que em sua escrita se apropriaram de uma forma metódica de produzir essa história da medicina. Portanto, para melhor entender como essas obras se solidificavam numa postura positivista, passo a discutir os livros e capítulos de livros!

Em A Paraíba e seus problemas, livro escrito por José Américo de Almeida e publicado no ano de 1923, é possível encontrar um capítulo dedicado às questões da saúde e da doença: $O$ saneamento. Embora o título do capítulo ${ }^{2}$ esteja diretamente atrelado às condições higiênicas, o autor ressalta as principais epidemias, endemias e doenças que atacaram os paraibanos. De acordo com Bárbara Silva (2015, p. 36), esse livro foi escrito atendendo a um pedido de Sólon de Lucena, que à época ocupava o cargo de Presidente do Estado da Paraíba. A obra devia funcionar como um "levantamento mostrando quais os problemas relacionados à seca na região eram enfrentados pelo governo e dando possíveis soluções para estes” (SILVA, 2015, p. 36).

N’O saneamento, décimo capítulo do livro, José Américo de Almeida (1923) defendeu que a "proteção sanitária seria uma medida de defesa econômica [na qual] a

\footnotetext{
2 O livro "A Paraíba e seus problemas" (1923) possui 14 capítulos distribuídos ao longo de 723 páginas, a saber: Terra ignota, O clima, $\mathrm{O}$ marítimo, $\mathrm{O}$ abandono, $\mathrm{O}$ homem do norte, A redenção, $\mathrm{O}$ problema das distâncias, Política hidráulica, $\mathrm{O}$ porto, $\mathrm{O}$ saneamento, a ação dispersa, Consequências sociais, Consequências econômicas e Impressão geral.
} 
higiene moderna tem uma ampla função de solidariedade [configurando-se como uma] vasta missão curativa e profilática" (ALMEIDA, 1923, p. 431-432). Iniciou seu texto contrapondo-se à afirmativa de Miguel Pereira, ao alegar que "a Paraíba não é uma enfermaria desse 'vasto hospital', desse país de doentes" (ALMEIDA, 1923, p. 432). Defendeu que a mortalidade na Paraíba só se tornou uma estatística elevada em tempos de irrupção das epidemias que associadas às grandes secas matavam em larga escala, além de anunciar que as endemias não possuíam um "caráter de gravidade" como em outras províncias/estados. É a partir desse momento que o autor parece se contradizer, pois passa a apresentar as doenças e epidemias que mais ceifaram vidas em terras paraibanas: a varíola, responsável pelo pódio de primeira epidemia conhecida ainda nos primeiros anos da colonização, grassando constantemente em corpos e rasgando vidas; a febre amarela, conhecida por "bicha" ou "males", adentrando livremente sob as asas dos mosquitos; o cólera-morbo que não poupou a Paraíba, fazendo com que "a nossa contribuição mortuária fosse, ao contrário, extraordinária" (ALMEIDA, 1923, p. 438), que foi atacada do litoral ao sertão, tanto em 1856 quanto em 1861; a peste bubônica na cidade de Campina Grande, no ano de 1912, importada do Recife, sendo "debelada em pouco tempo"; em 1918, a pandemia da gripe espanhola registrando só na capital 209 óbitos, sendo "as vítimas em sua maioria indigentes"; os constantes ataques de beribéri e dos parasitas intestinais onde se "abundam os meios de infestação", o impaludismo na forma "terçã benigna", de caráter endêmico, mas por vezes em forma de surtos epidêmicos; a doença de chagas, a encefalite letárgica e a meningite cérebro espinhal que também consumavam suas vítimas registradas nos obituários; o cancro e os tumores malignos que vinham "crescendo de forma notável [...] fornecendo um assombroso contingente à mortalidade" (ALMEIDA, 1923, p. 459); a lepra e a febre tifoide, que conforme o autor, "é muito rara nesse estado"; a bouba que esteve sempre "muito difundida pela população rural dos brejos, onde as moscas, abundantes no período das chuvas, transportam os germes e os inoculam na pele dos lavradores" (ALMEIDA, 1923, p. 460); a morbidez da sífilis, da tuberculose, da malária e da ancilostomose. Todas essas doenças são apresentadas a partir das más condições de higiene do estado, somado a fatores naturais como o clima, a vegetação, a existência de pântanos geralmente palustres onde os mosquitos se proliferam, o crescimento vertiginoso da população.

O capítulo é recheado de documentos oficiais como trechos dos relatórios presidenciais, anuários, tabelas com dados médicos de realização de exames, dados estatísticos de nascimento, crescimento da população e óbitos, registros de sepultamentos 
nos cemitérios, e claro, as ações de combate às doenças tomadas pelos governantes da época. Embora a proposta do livro timbrado nesse capítulo seja a de registrar os problemas de salubridade, não é apontada outra solução pelo autor senão a adoção de uma moderna higiene, pautada no saneamento básico, na profilaxia das ruas e na educação sanitária, como já vinha defendendo Flávio Maroja.

O capítulo batizado por O saneamento ainda possui a transcrição de pensamentos do higienista brasileiro Afrânio Peixoto, bem como, escritos de contemporâneos do autor, a exemplo de Coriolano de Medeiros. Trata-se da transcrição de parte de um artigo publicado na Revista do Instituto Histórico e Geográfico da Paraíba. O excerto selecionado é acompanhado da justificativa que visou apresentar como comprovação "os primeiros ensaios do serviço sanitário" tomados pelas esferas do poder público diante das "influências morbígenas, sem organização sanitária que nos assegurasse o prolongamento da vida" (ALMEIDA, 1923, p. 444). Esse "ensaios" transcrito anunciavam as medidas tomadas contra a varíola: vacinação e revacinação. Ou seja, dentre as medidas consideradas sanitárias utilizadas, a vacinação antivariólica parecia ocupar um protagonismo. Assim, percebo que o texto de José Américo de Almeida está permeado por uma escrita alicerçada numa história objetiva, dita verdadeira e científica, como convinha à época.

A Semana médica é um livro publicado no ano de 1927 como fruto do encontro "[...] realizado sob o patrocínio da Sociedade de Medicina e Cirurgia da Parahyba, no período de 3 a 9 de maio de 1927" e que reuniu médicos para discutir os principais problemas de saúde na Paraíba. À época, a referida sociedade era presidida pelos médicos Flávio Maroja, José Maciel e Oscar de Castro, que proferiram discursos que abrem a publicação. Nas palavras de Flávio Maroja (1927), a Semana Médica foi

[...] uma festa em família; é um trabalho todo regional, servido dos nossos próprios recursos, dando cada um de nós as provas de sua cultura e de suas aptidões de seus labores e de suas investigações, dos seus testemunhos, tudo vencido, embora entre os percalços, as responsabilidades e os dissabores da profissão [...] corre-se em busca d’um ideal representado num supremo bem que é a saúde.

Para José Maciel (1927, p. IX), o evento teve a função de “[...] estimular a classe médica, promovendo este certâmen scientífico, cuja eficiência prática será o engrandecimento da mesma”. Já para Oscar de Castro (1927, p. XI-XIII), o evento tratavase de uma "[...] comunhão de crentes, confundidos pelo mesmo ideal [ampliando] os tão majestosos horizontes da medicina preventiva [...] aqui estamos pelos sentimentos de patriotismo, batalhando pelo soerguimento do nosso homem”. Defendiam a reunião de 
esculápios que atuavam na medicina paraibana para discutir as formas de curar e prevenir as enfermidades, a adoção de uma educação sanitária e, sobretudo, fazer “[...] tudo pela eugenia - a ciência da transformação do homem” (MACIEL, 1927, p. XI). As questões vinculadas à "saúde da raça" ganharam tônica realçada nos discursos proferidos no evento e que pintou com tinta escura os discursos contidos nas páginas do livro Semana Médica.

O livro possui quatorze textos sobre o tema da saúde e da doença na Paraíba, escrito e apresentado por médicos. Para melhor visualizar, observe o quadro abaixo montado a partir dos textos contidos na Semana Médica:

Quadro 2. Trabalhos publicados no livro "Semana Médica"

\begin{tabular}{|c|c|}
\hline TíTULO & AUTOR \\
\hline Educação sanitária & Flavio Maroja \\
\hline A vacina contra a varíola e seus salutares effeitos & Teixeira de Vasconcelos \\
\hline A febre amarela é endêmica na Parahyba? & José Maciel \\
\hline Prophylaxia da tuberculose na Parahyba do Norte & Alfredo Monteiro \\
\hline As creanças anormaes & Seixas Maia \\
\hline Considerações sobre a profilaxia da lepra no Brasil & Jósa Magalhães \\
\hline $\begin{array}{c}\text { Considerações sobre um caso de insuficiência mitral com sopro } \\
\text { circular de Miguel Couto }\end{array}$ & Renato V. de Azevedo \\
\hline Um capítulo de hygiene intelectual do trabalho escolar & Oscar de Castro \\
\hline Duas observações de uma clínica cirúrgica & Tito Mendonça \\
\hline Antigos conceitos do alienado & Octávio Soares \\
\hline Seringa vesical de Guyon, typo Record & Edrise Villar \\
\hline Algumas considerações sobre a loucura maníaco-depressiva & Octávio Soares \\
\hline Ligeiras considerações em face de alguns medicamentos novos & Lourival Moura \\
\hline A peste na Parahyba & Flávio Maroja \\
\hline
\end{tabular}

Fonte: Quadro elaborado pelo autor a partir dos dados contidos no livro "Semana Médica" (1927).

Num primeiro passar de olhos, é possível perceber que os trabalhos apresentados versaram sobre três eixos temáticos: a educação sanitária, a tecnologia médica (seringas, cirurgias e medicamentos) e as doenças (febre amarela, tuberculose, lepra, insuficiência mitral, loucura, depressão, peste bubônica), sendo este último majoritário em relação aos demais. De acordo com Leonardo Santos (2015, p. 193), esses textos também foram publicados nas primeiras páginas do jornal A União entre os meses de setembro de 1927 e março de 1928. Até mesmo aqueles "de teor mais especializado, como relatos de casos clínicos e de intervenções cirúrgicas, foram integralmente dados à leitura pelas páginas do jornal oficial” (SANTOS, 2015, p. 193).

Quero me deter a características presentes nos textos dedicados às enfermidades. Todos eles possuem um caráter histórico: seus autores médicos fizeram uma espécie de apanhado sobre a história da doença, por vezes seguindo a escala planeta-país-estado, e apresentando dados de períodos históricos mais distantes temporalmente, a exemplo do 
período colonial e imperial na Paraíba. Possivelmente, esses médico-escritores tiveram acesso à documentação do Instituto Histórico e Geográfico da Paraíba (IHGP) e a partir dessas fontes históricas, compostas em geral por relatórios, dados estatísticos, anuários, notícias de jornais e as produções sobre o tema do início do vigésimo século, produziram seus escritos sobre as doenças. São poucos os textos que avançam no sentido de apresentar debates científicos em voga e que fossem considerados úteis à prática médica da época. Os textos sobre as doenças se aproximavam da produção publicada na Revista do IHGP, ressaltando que boa parte desses médico-escritores também eram sócios do instituto que se dizia "guardião da memória". Se os saberes apresentados na Semana Médica pouco serviram para o aperfeiçoamento dos profissionais, é certo afirmar que eles contribuíram para enriquecer de informações aqueles que futuramente se debruçariam sobre a história das doenças. Alguns desses textos possuem dados que não são mais encontrados nas fontes históricas à disposição dos historiadores.

A eugenia é outro ponto que merece destaque na observação dessa obra. Presente em alguns dos textos de forma mais aparente, como na Educação sanitária, em As creanças anormaes e em Um capitulo de bygiene intelectual do trabalho escolar, em outros, o tema aparece nas entrelinhas, como nas Considerações e profilaxia da lepra no Brasil e Algumas considerações sobre a loucura maniaco-depressiva. Defendia-se a "salvação da raça", tentando incutir nos seus pares o desafio de educar "[...] a nossa gente a ideia da consciência sanitária”" (MAROJA, 1927, p. 7). O sanitarista Flávio Maroja prezava pela adoção de um modelo eugênico-sanitário idêntico ao utilizado nos Estados Unidos, onde "educação e propaganda sanitárias tem conseguido o bem-estar da saúde do povo [...] não sofrem objecções e são acolhidas com todo o interesse e atenção” (MAROJA, 1927, p. 8). Indicou a orientação de exames físicos nas crianças baseados na inteligência para verificar sua anormalidade. Para tanto, o Dr. Seixas Maia, em seu texto, orientava os médicos a observarem os “[...] caracteres exteriores e a tudo que se relacionar com a memória, emotividade, afetividade e atividade voluntária, pesquisando a causa do déficit intelectual, examinar o esqueleto, a sensibilidade dos órgãos e as glândulas de secreção interna" (MAIA, 1927, p. 49). Ou ainda verificar as causas hereditárias que facilitariam o diagnóstico: “[...] syphiles e alcoolismo dos pais são frequentemente a causa da degeneração da descendência” (MAIA, 1927, p. 49). Sendo diagnosticada alguma anormalidade como epilepsia e histeria, anormalidade física, moral ou intelectual, a saber, “[...] cegos, surdos, idiotas, cretinos, imbecis, paralíticos e os atingidos de perversão dos instintos" (MAIA, 1927, p. 49-50), era preciso adequar a educação da criança sob a responsabilidade dos médicos. Por fim, a eugenia apareceu na fala de Oscar 
de Castro sobre a higiene dos escolares. O médico defendeu que a infância era a fase da vida de maior fragilidade e, portanto, a que mais precisava de cuidados higiênicos. De acordo com o esculápio, a casa e a escola deviam livrar-se das estruturas contrárias às leis da pedologia e os alunos deviam evitar ao máximo a fadiga física e mental, sendo "[...] a verdadeira hygiene escolar aquella que previne os efeitos do cansaço [pois] desde os tempos remotos nos pregavam os sábios romanos - mente sã, corpo são” (CASTRO, 1927, p. 88). A defesa da eugenia estava diretamente ligada às condições de higiene.

Como já foi dito, o livro recebeu o mesmo título do evento dito científico e funcionou como uma espécie de anais da Semana Médica. Os autores dos trabalhos apresentados eram todos médicos que se dedicaram a discutir o que eles chamaram de história das enfermidades que atacaram a população paraibana em forma epidêmica, como a varíola, a febre amarela e a peste bubônica, ou de forma constante como a lepra, a tuberculose e a loucura. Trata-se de uma produção da história das doenças escrita por uma geração de médicos que acreditava estar escrevendo a "verdadeira história das enfermidades", um legado para a posteridade. As referências utilizadas ao longo dos textos são de autores estrangeiros, sendo poucos médicos e estudiosos brasileiros citados. É possível registrar a predominância da influência europeia nas leituras dos médicos paraibanos, como comum no início do século a maioria das ciências.

Dessa forma, é possível afirmar que a obra Semana Médica pode ser vista como uma coletânea discursiva sobre a história da saúde e das doenças na Paraíba. Abria-se naquele momento espaço para outras formas de publicação de fôlego sobre o tema, a exemplo da Revista Medicina e do livro História da Medicina, de Oscar de Castro, publicado no ano de 1945.

Esse último, tornou-se a principal referência aos estudiosos do campo da saúde e das doenças na Paraíba. Trata-se da primeira obra na qual

[...] Oscar de Castro foi cirandar os elementos preciosos que fartaram este livro [...] cada personagem pela mão e a capacidade espiritual desses desaparecidos batalhadores que, além da campanha pela saúde pública, se empenharam no levantamento do nível mental dos seus concidadãos (MEDEIROS, 1945, p. III-IV).

Medicina na Paraíba é um livro de um "estilo sóbrio e bem cuidado, olhando o panorama criterioso dos quadros, retratos fidelíssimos dos memorandos profissionais que integram uma sociedade [médica]" (MEDEIROS, 1945, p. III), e que fala sobre as práticas de saúde na Paraíba de forma a "olhar de frente um dos mais curiosos aspectos da família conterrânea no seu passado, no seu presente, com auscultação do seu futuro" 
(MEDEIROS, 1945, p. IV). Nas palavras de Coriolando de Medeiros (1945, p. VII), o autor do livro era um homem digno e que vivia para a profissão médica, família e amigos. No prefácio que abre a obra, assim o descreveu:

[...] na hora do sofrimento físico, é médico; na hora das lições é professor; nos momentos precisos, sabe ser paraibano; é cientista e nas horas de lazer, intelectual meritoso, jamais afastando-se dos limites de intangível modéstia. Espírito brilhante, forjado na escola paciente da observação, do estudo e das pesquisas, suas opiniões são recebidas sempre entre acordes de profundo acatamento (MEDEIROS, 1945, p. VII).

As adjetivações ao médico e escritor Oscar de Castro ganharam tons itálicos na escrita que prefaciou Medicina na Paraíba. O médico foi descrito como um cientista atento à pesquisa do passado, responsável por divulgar práticas educativas da cura, por atender os enfermos na hora da angústia do corpo e um patriota de sua terra, sendo sempre presente nos momentos precisos. Sua obra foi apontada como necessária para entender o passado da saúde e assegurar de forma metafórica a ausculta do futuro; saber escrito que visou cristalizar o nome de médicos, seus auxiliares, boticários, enfermeiros, ou, "um tributo carinhoso e merecido, pois todos, na relatividade de sua inteligência e de seus esforços, concorreram para traçar a estrada, por onde, até os dias atuais, vem palmilhando a medicina da região" (MEDEIROS, 1945, p. V).

O livro foi publicado pela Editora $A$ União, que também era responsável por publicar o jornal de mesmo nome e que pertencia ao Governo do Estado da Paraíba. Acredito que a impressão do livro tenha sido financiada pelo poder público, visto que parte dos médicos que atuavam em sociedades do saber acumulavam cargos públicos de destaque, seja por indicação ou pleiteando o voto popular.

Com 442 páginas, a publicação está dividida em dezessete capítulos, sendo o primeiro, responsável por ocupar 193 páginas: Vultos médicos do passado. Esse capítulo foi dedicado a biografar "as mais notáveis figuras médicas do passado", sob a alegação de que a Paraíba "têm para com aqueles a quem o destino colocou na defesa da saúde, uma grande dívida, enorme, acrescida por juros que o tempo acumulou" (CASTRO, 1945, p. 14). O médico destacou na lista dos "profissionais da arte de Hipócrates" aqueles que considerou terem sido "grandes clínicos", "médicos e homens de letras", "médicos e políticos" e a "extraordinária figura de naturalista, precursor de nossa emancipação política, que foi Arruda Câmara” (CASTRO, 1945, p. 15).

A lista dos médicos biografados está organizada em forma cronológica de atuação, apresentando além de informações pessoais e profissionais, documentos produzidos por 
esses médicos, em geral, relatórios, trechos de artigos publicados em jornais, falas públicas ou mesmo ilustrações produzidas especialmente para o livro, de autoria do "pintor Barros - o mulato". Ou como o próprio autor narrou: "relatórios, polêmicas, instruções, discursos, poesias e o pensamentos médicos" (CASTRO, 1945, p. 192). O primeiro biografado foi o naturalista Arruda Câmara, que teve atuação na Paraíba após ter se formado em medicina na Faculdade de Montpelier na França em 1889. O último biografado foi o Dr. Manuel Correia da Cunha, formado pela Faculdade de Medicina do Rio de Janeiro e atuando na Paraíba a partir de 1921 como médico da Saúde Pública até 1938. No decorrer do capítulo, nomes de médicos "renomados" como João José Inocencio Poggi, Abdon Milanez, Antônio da Cruz Cordeiro Sênior, Antônio da Cruz Cordeiro Júnior, Flávio Maroja, Walfredo Guedes Pereira, Eugênio Toscano de Brito, José Lopes, Paulo Lacerda, dentre outros, aparecem na lista dos que foram considerados "vultos médicos do passado".

Ao todo, foram apresentados 31 esculápios, com ou sem formação em medicina, sendo exaltados em sua formação, sua atuação médica e sua contribuição para a medicina em termos de alguma publicação na área. Ao término do capítulo, Oscar de Castro (1945, p. 1921) afirmou que muitos médicos deixaram de figurar por insuficiência de dados: "Escaparam paraibanos ilustres, que aqui vieram e lutaram, ou daqui saíram para outros meios". Enfatizou que esses profissionais "deram a medicina muita dignidade, souberam mantê-la em elevado padrão, serviram a causa pública com anthusiamos, cultuaram a língua e amaram a beleza (CASTRO, 1945, p. 192), são médicos que "hão de continuar constituindo o substrato sobre o qual se apoia o vertiginoso progresso da ciência médica" (CASTRO, 1945, p. 193).

Os demais capítulos são mais curtos em número de páginas, tendo cada um deles de dez a quatorze páginas, à exceção do capítulo décimo sexto, intitulado Instituições médicas e de assistência que possui um total de 67 páginas e o décimo sétimo, batizado por "Legislação médica" com a quantia de 22 páginas. Para melhor apresentar os capítulos que formam o livro Medicina na Paraíba, observemos o quadro abaixo:

Quadro 3. Capítulos do livro Medicina na Paraíba (1945).

\begin{tabular}{|c|c|c|}
\hline CAPÍTULO & TÍTULO DO CAPÍTULO & PÁGINAS \\
\hline 1 & Vultos médicos do passado & 193 \\
\hline 2 & Transportes e trajes dos médicos antigos & 11 \\
\hline 3 & Através dos anúncios e solicitadas dos jornais & 10 \\
\hline 4 & Os médicos e a política & 12 \\
\hline 5 & Como era a cirurgia & 14 \\
\hline 6 & A higiene & 10 \\
\hline 7 & Doenças e diagnósticos \\
\hline
\end{tabular}




\begin{tabular}{|c|c|c|}
\hline 8 & Epidemias & 14 \\
\hline 9 & Exercício ilegal da medicina & 14 \\
\hline 10 & Homeopatas e naturalistas & 10 \\
\hline 11 & Enfermeiros & 8 \\
\hline 12 & Parteiras & 10 \\
\hline 13 & Medicina caseira e popular & 10 \\
\hline 14 & Como se usava a sangria e se ajudava a morrer & 10 \\
\hline 15 & Cerimônias fúnebres & 12 \\
\hline 16 & Instituições médicas e de assistência & 61 \\
\hline 17 & Legislação médica & 22 \\
\hline
\end{tabular}

Fonte: Quadro elaborado a partir de dados contidos no livro Medicina na Paraíba (1945).

Uma característica marcante nessa obra é a quantidade de documentos transcritos e publicados na íntegra sobre o tema da saúde e das doenças. Os capítulos são compostos pelo discurso escrito do autor no sentido de dar um protagonismo aos envolvidos com a saúde paraibana. Os médicos são os personagens centrais dessa obra, lhes sendo atribuídos três capítulos do enredo: Vultos médicos do passado, Transportes e trajes dos médicos antigos, Os médicos e a politica, bem como sua aparição nos demais, de forma direta ou indireta.

Em Transportes e trajes dos médicos antigos, Oscar de Castro afirma que os trajetos percorridos pelos esculápios ocorriam a pé ou a cavalo, ou melhor, em "bons cavalos". Além dos animais, as aranhas e as cabriolés ganharam moda entre os médicos no oitocentos. O registro do primeiro automóvel utilizado por médicos só ocorreu em 1909. Já os trajes de médicos foram detalhados nesse capítulo a partir de fotografias dos ditos doutores Poggi e Krause: "vestidos em solenes sobrecasacas, colarinhos de grande altura em sobre o peito as insígnias de comendadores". A elegância parecia ser regra nas vestimentas, mesmo no alvorecer do vigésimo século quando os "médicos transitam velozes, cortando a cidade em todos os sentidos em busca de seus doentes" (CASTRO, 1945, p. 204). Por fim, a saudosa queixa: “as tradições passam”. Já em Os médicos e a política foi descrito o "grande número de médicos [que] tem desertado dos labores da profissão atraídos pela política” (CASTRO, 1945, p. 217). O autor fala que ao estudar a história dos movimentos políticos na Paraíba é possível encontrar com frequência o nome de médicos dando as cartas do jogo político ou sendo lançados ao ostracismo. Nesse sentido, faz uma rápida retrospectiva dos movimentos em que esses sujeitos atuaram mais fortemente, certo de que em "seu sacerdócio ou chamado a vida pública, o médico muito pode fazer pela coletividade ou pela causa que abraçou", pois eram donos "formação de espírito e estribado em elevada ética" (CASTRO, 1945, p. 226).

Em Através dos anúncios e solicitadas dos jornais foi apresentado a "moda do anúncio" na qual a medicina não poderia ficar à margem, ofertando os produtos das boticas, os medicamentos dos consultórios e dos próprios médicos. Como era a cirurgia é o quinto 
capítulo, descrevendo os horrores praticados com um bisturi que abria corpos e "deixavam os doentes entregues a própria sorte”. Nessa altura do texto, Oscar de Castro transcreve com suas palavras a história de Thomaz Camboia e a extração de um tumor de sua perna. Tratava-se de uma história que já havia sido publicada em forma de notícias em jornais em circulação no século XIX, mesmo que o autor não faça a menor referência a eles. $\mathrm{Na}$ Higiene, foram publicadas informações sobre o "Serviço de Higiene da Paraíba", descrevendo seus líderes e seus feitos, a exemplo dos cuidados com a Malária contidos no documento do Serviço Nacional de Malária, produzido pelo Departamento Nacional de Saúde e publicado na íntegra nas páginas que foram esse capítulo. Doenças e diagnósticos é o capítulo seguinte no qual é apresentada a atuação de alguns médicos no enfrentamento às doenças. Em seguida, Epidemias, contendo a transcrição de trechos de relatórios médicos e dos chefes da Província diante das epidemias de febre amarela, varíola, cólera e peste bubônica.

O novo capítulo Exercício ilegal da medicina conta a história daqueles que se dedicavam à arte de curar sem uma formação científica: os curandeiros, charlatões, rezadores, farmacêuticos, dentre outros. Na Homeopatia e naturistas, Oscar de Castro (1945, p. 293) lida com o "método terapêutico [na qual] a química só vinha aos poucos". Nos Enfermeiros, o autor parte do imperativo de que "nossos antigos enfermeiros não passavam de práticos, que de tanto lidar com doentes adquiriam habilidade no trato das enfermidades" (CASTRO, 1945, p. 303). As Parteiras é o título do tema do décimo segundo capítulo do livro. Elas eram responsáveis por realizar partos, orientar as grávidas e dar os primeiros cuidados aos corpos das crianças. Na Medicina caseira e popular os chás, efusões e garrafadas ganham destaque, indicando-os no tratamento das enfermidades, nos escritos do médico. Como se usava a sangria e se ajudava a morrer, capítulo seguinte, apresenta-se o uso das sangrias como método terapêutico considerado de "grande valia e eficácia comprovada", por meio da sangria, da sanguessuga, do purgante e do clister. As Cerimônias fúnebres possui a tônica das homenagens prestadas aos mortos que sofreram mudanças com o passar do tempo: os primeiros cuidados ao morto, a comunicação do óbito, as cartas de enterro, o cortejo, o enterramento e os cemitérios.

Os dois últimos capítulos do livro foram nomeados de Instituições médicas e de assistência, dedicados a contar a história dos hospitais construídos em tempos de surtos epidêmicos, ou na forma de prover a dita "saúde pública" através das Misericórdias, como modelo de assistência à população. Nesse capítulo, apresenta-se um resumo histórico sem referência à fonte, dos hospitais, manicômios e orfanatos que tiveram uma vida breve ou 
longa desde meados do século XIX na Paraíba; e, a Legislação médica, que tratou de publicar na íntegra as leis provinciais que regulamentavam o exercício médico paraibano.

Reafirmo que os capítulos que compõem o livro Medicina na Paraíba adotaram um tom saudosista. Os médicos com seus trajes, transportes e atuação profissional e política; os enfermeiros, as parteiras e os curandeiros com suas práticas de cura, são lembrados com a tônica de um modelo que ficou no passado. Vez por outra, o autor deixa escapar que os tempos (meados do século XX) sofreram consideráveis alterações, não sendo mais possível ver os médicos cavalgarem com anéis de esmeralda no dedo ou mesmo com uma bengala com cabo de ouro ou prata. A ordem de seu discurso indica o aparecimento de um possível “desprestígio" social na imagem do médico, provocado pela abertura de novos cursos de medicina para além da fábrica de formar esculápios na Bahia e no Rio de Janeiro, pelo crescimento da população e o número de doenças e doentes; pelo avanço dos cuidados com o corpo, num momento em que as doenças eram tratadas e medicadas na ordem do privado, sem exposição espetacular das cirurgias como ocorriam no oitocentos, e, também, pela perda de espaço na política para militares e civis prestigiosos. Seus escritos podem ser entendidos como uma memória com o intuito de fazer rememorar nomes de indivíduos que contribuíram na arte de curar, de impedir seu apagamento, de não permitir que seus feitos despencassem no abismo do esquecimento. Oscar de Castro escreveu com a pena da saudade, ergueu altares para prostrar santos-médicos, narrou feitos políticos que bordaram a imagem desse ou daquele todo-poderoso que "conquistou" reconhecimento popular dentre uma elite letrada por "investir" na saúde pública. Suas palavras escritas estão metodicamente ancoradas num rosário de bendizer em que prevalece a paixão pelo documento e pela política em detrimento ao científico. A função da sua história da Medicina na Paraíba era "recuperar os eventos, suas interconexões e suas tendências através da documentação e fazer-lhes a narrativa [na qual] a história se limitaria a documentos escritos e oficiais e eventos políticos" (REIS, 1999, p. 12).

Fruto de uma época e de um dado lugar social, a obra Medicina na Paraíba contribui com os atuais historiadores da saúde e das doenças não só com sua narrativa ordenadamente cronológica permitindo conhecer possíveis fatos não mais encontrados em outras fontes históricas, mas por viabilizar o acesso a um acervo documental publicado naquilo que ele julgou ser um livro repleto de "rigorosa crítica". Muito parecido com o que fez Humberto Nóbrega no livro As raízes das ciências da saúde na Paraíba, publicado pela Editora da Universidade Federal da Paraíba no ano de 1979. 
Com a proposta de buscar as raízes, ou seja, as origens da saúde na Paraíba, Humberto Nóbrega (1979, p. 11) afirmou ser para "qualquer comunidade, um trabalho fascinante". O ídolo das origens, ou a busca incessante por um começo, esteve presente na obra desde o título metaforizado pelas "raízes", que estão embaixo da terra e não são vistas, portanto, desconhecidas. Esse lugar de difícil acesso parece ser colocado como o lugar a ser alcançado. Para tanto, afirmou apresentar "os estágios vencidos pela arte de curar, até atingir o conceito hodierno de higidez", as formas de "curar os enfermos, aliviar os sofrimentos e dores dos que padecem" (NÓBREGA, 1979, p. 11) e elencar as descobertas ditas médicas, dos práticos até as raízes medicinais do transplante de órgãos vitais, é apontado como proposta a ser discutida na obra.

O livro possui vinte e sete capítulos distribuídos ao longo de 372 páginas. A maioria dos capítulos são parecidos com o formato adotado por Oscar de Castro em Medicina na Paraíba, a exemplo dos capítulos sobre os médicos, que são apresentados em forma de lista acompanhada de um resumo de suas biografias e, em alguns casos, a transcrição de documentos produzidos por ou sobre eles, ou mesmo, propagandas de seus consultórios clínicos. A tônica central da obra são os médicos: os pioneiros, de antanho, generais, militares, clínicos, sua relação com outros profissionais, sua atuação nas faculdades e nos hospitais, sua disputa por espaço com os práticos sem formação e sua organização em sociedade - a Sociedade de Medicina e Cirurgia da Paraíba. A enfermagem, a odontologia e a farmácia aparecem na obra de forma institucionalizada: através da criação da Escola de Enfermagem, responsável por formar os profissionais do cuidado, da Faculdade de Odontologia, edificando dentistas, e da Faculdade de Farmácia, gestando os farmacêuticos que reivindicaram espaço com os práticos ditos farmacêuticos do passado.

No geral, o texto de Humberto Nóbrega visou cristalizar a imagem e o nome de médicos e outros profissionais da saúde que se destacaram em seu exercício. Almejou instituir uma "história verdadeira" desde sua origem, passando pela institucionalização médica até a apresentação da formação desses profissionais na Paraíba com a construção das faculdades na área da saúde. O autor parece ter reunido nesse texto "um número significativo de fatos, que são 'substâncias' dadas através dos documentos 'purificados' restituídos a sua autenticidade externa e interna" (REIS, 1999, p. 13). Uma obra que se tornou leitura "obrigatória" para aqueles que se dedicam a pesquisar a histórica de causos médicos, a biografia de médicos, as artes de curar e a profissionalização da saúde. Narrativa e transcrição de documentos marcam o livro As raízes das ciências da saúde na Paraíba. 
Em A velha Paraíba nas páginas dos jornais (1999), Wellington Aguiar presta um bom serviço aos pesquisadores da saúde e das doenças do século XIX na Paraíba que não possuem acesso às "sociedades fechadas", que guardam seus documentos a sete chaves: publicou notícias contidas nos jornais sobre $A$ vida e a morte - anúncios, epidemias, mezinhas e hospitais. Trata-se da Unidade $V$ do livro que traz em forma de crônica curta, recortes e imagens desses documentos sobre os mais variados temas: nascimento e morte, cirurgia, notas fúnebres, cemitérios, medicamentos e elixires do passado, epidemia de cólera, higiene, endemias, febres e hospital do século passado.

Após apresentar rapidamente o tema debatido, o autor entranha aos seus escritos, trechos dos documentos, deixando evidente ao leitor a fonte de onde foram retirados: os jornais e a data da publicação. Todos os 31 textos que compõe essa unidade do livro variam de duas a três páginas sob o mesmo formato. Não é possível encontrar uma análise, pois essa não parecia ser a proposta da obra, mas sim, apresentar o assunto e confirmar a afirmação com a transcrição do documento. Nesse caso, o documento servia para validar, para dar um tom de veracidade àquilo que era escrito em forma de imperativo pelo autor.

Já no Dicionário biográfico dos médicos da Paraíba, publicado no ano de 2014, pelos médicos José Eymard de Medeiros e José Morais Lucas, é possível encontrar uma "homenagem a todos aqueles profissionais, desde os mais laureados até os menos conhecidos, que exerceram suas atividades no mais longínquo município de nosso Estado" (MEDEIROS; LUCAS, 2014, p. 13). O dicionário organizado em ordem alfabética está dividido em três capítulos: no primeiro, História da medicina na Paraíba, sendo apresentado de forma cronológica, do século XVI ao XIX. Esse capítulo é bastante curto e apresenta através dos anos a descrição de acontecimentos como epidemias ou mesmo atuação de algum médico. Não há a construção de uma narrativa, apenas a indicação dos acontecimentos ou uma rápida descrição dos predicados médicos. O capítulo segundo, Médicos de antanho, e capítulo terceiro, Médicos paraibanos, são formados pela sequência alfabética contendo fotografia ${ }^{3}$, nome completo e uma pequeno resumo da biografia desses esculápios. A maior parte das informações dos médicos que exerceram sua profissão numa periodicidade mais distante temporalmente, foi retirada das obras Medicina na Paraíba, de Oscar de Castro e de As raízes das ciências da saúde na Paraíba, de Humberto Nóbrega. Os médicos paraibanos temporalmente próximos dos autores dos livros, foram escritos pela juntada de informações de familiares ou mesmo pelo conhecimento assegurado pela

3 Nem todos os médicos possuem imagens. Alguns são representados por fotografias, outros pinturas, outros desenhos. Os autores não revelaram de qual arquivo conseguiram a imagens. 
memória. O critério para ser biografado na obra foi ter possuído atuação médica e já ter falecido.

Uma característica dessa obra que merece destaque é a presença de mulheres médicas a partir da primeira metade do vigésimo século. Embora o espaço seja majoritariamente masculino, após a década de 1930, as mulheres vão ganhando espaço na medicina. Destacam-se as figuras de Eudésia Vieira e Neusa Andrade que se formaram na Faculdade de Medicina do Recife no ano de 1934. Eudésia Vieira tornou-se conhecida por clinicar na área da ginecologia e obstetrícia, bem como, por seus escritos na imprensa paraibana. $^{4}$

O "Dicionário biográfico de médicos da Paraíba" é mais uma das obras que pode ser considerada fonte histórica para os pesquisadores do campo. É um livro que cumpre sua função técnica de apresentar dados e fatos sobre os médicos paraibanos, sendo em cada um deles enfatizada sua formação, atuação médica, política e benefício para a sociedade local. Em suas anotações, os médicos são apresentados de forma imaculada, sendo ressaltadas apenas suas "honrosas" contribuições para a saúde da população paraibana.

Essas obras acima apresentadas se assemelham por diversos motivos: a) são parte integrante de uma primeira geração de trabalhos sobre o campo da história da saúde e das doenças na Paraíba, em sua maioria produzidos por médicos e intelectuais vinculados às sociedades do saber (portanto, não historiadores); b) considero esses trabalhos como importantes registros sobre médicos, práticos de saúde, doenças, epidemias, condições de higiene, educação sanitária, dentre outros, portanto fonte histórica para o campo; c) assumem o caráter descritivo e pouco analítico sobre os temas anotados, reproduzindo em sua maioria a transcrição de documentos que ficaram guardados a sete chaves nos baús das casas de memória ou que se perderam ao longo do tempo; d) possuem um caráter saudosista rememorando o prestígio médico-político que esses homens de jaleco possuíam, atribuindo-lhes sempre adjetivações como caridade, trabalho incansável, protetores dos pobres doentes, donos de índoles sem mácula alguma; e) os textos heroificam os profissionais médicos do século XIX e início do vigésimo século, considerando-os como "grandes homens", característica própria de uma historiografia metódica que se limitava a descrever fatos como prova de uma história universal, forte apego ao documento permitindo-os produzir um conhecimento confeccionado à base da imparcialidade,

4 Eudésia Vieira concluiu seu curso em 1934, sendo nomeada a primeira doutora da Paraíba e da Faculdade de Medicina do Recife, por ter defendido a tese intitulada "Syndrome de Schickelê", também apresentada no Segundo Congresso de Médicos da cidade do Recife (GALVÍNCIO, 2019, p. 93-94). 
narrando o fato histórico "como ele realmente aconteceu"; f) a primeira forma de produzir história da saúde e das doenças na Paraíba esteve atrelada a questões políticas, seja no sentido de prestar conta dos "feitos", seja na adoção de um tom denunciativo para ajustes no funcionamento da saúde pública, ou em acusações discursivas de caráter político partidário.

Essa primeira geração de escritos sobre o tema, reafirmo, se configura enquanto importante contribuição, sobretudo, para os historiadores que tomaram para si o debate médico como parte constituinte do campo da história da saúde e das doenças, gestando assim a segunda geração, caracterizada pela tessitura de trabalhos acadêmicos (dissertações e teses $)^{5}$ produzidos por pesquisadores de diversas áreas sobre a história da saúde e das doenças em Programas de Pós-Graduação fora e dentro da Paraíba, num momento em que as fontes históricas em grande parte já se encontravam disponibilizadas em arquivos públicos $^{6}$ e virtuais ${ }^{7}$ (hemerotecas).

\section{A SEGUNDA GERAÇÃO}

O primeiro trabalho nesse perfil, do qual tenho conhecimento, foi a tese defendida no Programa Interunidades de Doutoramento em Enfermagem da Universidade de São Paulo, no ano de 1999, por Lenilde Duarte Sá ${ }^{8}$, intitulada Parabyba: uma cidade entre miasmas e micróbios. O Serviço de Higiene Pública, 1895 a 1918. A autora se dedicou a entender a trajetória do Serviço de Higiene Pública através de sua regularização, implementação, organização e falência. Nesses escritos, a autora defende a existência de uma política

5 Alguns desses trabalhos acadêmicos foram publicados posteriormente em formato de livro.

6 Dentre os principais arquivos que possuem documentos contendo fontes históricas para o campo da história da saúde e das doenças na Paraíba é possível citar na cidade de João Pessoa, o Arquivo Público do Estado da Paraíba, o Arquivo da Santa Casa de Misericórdia, o Arquivo Eclesiástico, a Fundação Casa de José Américo de Almeida, o Arquivo Maurílio de Almeida, o Arquivo do Instituto Histórico e Geográfico da Paraíba, o Arquivo João José Inocêncio Poggi (localizado no Hospital Juliano Moreira), o Arquivo da Sociedade de Medicina e Cirurgia da Paraíba, a Coleção de Obras Raras da Biblioteca da UFPB; na cidade de Campina Grande, o Arquivo Átila de Almeida (localizado na UEPB), o Arquivo Municipal da cidade de Campina Grande.

7 É importante destacar que a Hemeroteca Digital da Biblioteca Nacional disponibiliza em rede parte do acervo (jornais, relatórios de presidentes de Província, revistas) que pode ser consultado pelo historiador do campo da saúde e da doença; a Hemeroteca do Centro de Ciências Humanas, Letras e Artes da UFPB, intitulada Jornais e Folhetins, onde é possível encontrar digitalizado parte dos impressos paraibanos do século XIX; e o Acervo Digital do Jornal A União, disponível na página do próprio impresso, contendo um considerável número de exemplares digitalizados desde o ano de sua fundação em 1893 até o ano de 2021.

8 Lenilde Duarte Sá graduou-se no Curso de Habilitação em Saúde Pública, fez mestrado em Saúde Pública na UFPB, defendendo a dissertação intitulada "Atividades antimicrobianas de extratos vegetais e óleos essenciais sobre bactérias causadoras de conjuntivite: uma abordagem fitoterápica em Enfermagem de Saúde Pública". Fez doutorado na Escola de Enfermagem da USP. Foi professora do Departamento de Enfermagem da UFPB a partir do ano de 1993. Ao longo de sua trajetória profissional, dedicou-se ao estudo da higiene pública, da saúde coletiva, da tuberculose, dentre outros. Faleceu em junho de 2017. 
policialesca e repressiva, quando na verdade, deveriam adotar uma educação disciplinadora, sanitária. A tese está dividida em quatro capítulos: Sobre a cidade da Parabyba, na qual é apresentado um "retrato" descritivo da organização urbana do espaço social, a chegada dos retirantes fugidos da seca e que buscavam na capital uma melhor condição de sobrevivência, e como a cidade foi remodelada a partir da chegada desses ditos "flagelados", provocando aquilo que Lenilde Sá chamou de "odores sociais", nesse caso, os maus odores, incômodos para uma elite que precisava caminhar pelas calçadas possivelmente tapando o nariz para não ser afetada pela catinga que exalava dos corpos amontoados nessas espacialidades públicas; A cidade da Parabyba e a República, momento em que a autora mergulha nas disputas político-partidárias entre Conservadores e Liberais, exatamente quando a Paraíba recebeu a notícia da Proclamação da República, levando em consideração as parcas mudanças ocorridas no cenário político, sua sutil reorganização com a promoção de oligarquias que ascendem e declinam como numa gangorra do poder. Tratase de um capítulo de história política, no qual as questões sobre higiene pouco aparecem, a não ser pela narrativa, também de cunho político, de uma sublevação de mulheres pobres, pedintes e fedorentas, que foram manipuladas pelos políticos para tornar-se notícia jornalística e promover acusações. A metáfora da epidemia é o capítulo dedicado à varíola e seus surtos grassados na transição da temporalidade analisada. Além de descrever as várias epidemias das bexigas, a autora investe na descrição, e pouca análise, acerca dos discursos médicos de vacinação e revacinação. É o único capítulo da tese em que Lenilde Sá se dedica à história de uma doença: a peste rubra. Por fim, O Serviço de Higiene Pública, discutido no quarto capítulo, no qual a autora discute a legislação da época responsável por regular o referido serviço; em seguida aponta as principais dificuldades enfrentadas pelos médicos que atuavam nessa repartição pública, a exemplo da falta de investimento financeiro e de profissionais (médicos, enfermeiros, inspetores, fiscais), culminando com seu declínio em 1911. Os anos que seguem (1912 a 1918) foram marcados pela ausência de um sistema de higiene capaz de incutir um modelo de educação sanitária, fazendo com que epidemias diversas eclodissem nos mais diversos recônditos da Paraíba, como a peste bubônica em Campina Grande no ano de 1912 e a Gripe Espanhola em 1918, a princípio na capital, e de lá, se espalhando para o interior do estado.

A documentação utilizada por Lenilde Sá é composta basicamente pelas notícias de jornais da época e alguns relatórios médicos e políticos. No tempo da escrita desse texto, a consulta aos documentos nos arquivos era realizada à base da cópia manual das informações, pois câmera digital, scanner ou qualquer outro artefato tecnológico ainda era 
artigo raro e caro. Apesar disso, a autora apresenta um grande acervo documental no decorrer de seu texto.

É preciso afirmar que esse não é um texto sobre história das doenças, especificamente, mas um escrito próprio de uma época em que se buscava, através da história política, perceber os usos dos problemas sociais como instrumento de acusação político-partidário, "fatos que nos levam a sugerir que acontecimentos políticos tenham sido determinantes para sua institucionalização" (SÁ, 1999, p. 5). Embora a tese adote um tom de história política, a autora faz boas análises das fontes, sobretudo nos dois últimos capítulos, que em suas palavras, “elementos econômicos, políticos e sociais, devidamente articulados, concorreram para que esse serviço assumisse uma feição própria [...] não revelando apenas um aspecto do nosso passado" (SÁ, 1999, p. 5) mas que "acima de tudo [pudesse] servir para enriquecer o conhecimento que vem sendo elaborado na área da Saúde Coletiva" (SÁ, 1999, p. 6).

Se o primeiro trabalho acadêmico de fôlego foi produzido em 1999, os demais tiveram que aguardar pouco mais de uma década para serem produzidos. Para melhor apresentar as dissertações e teses defendidas nos Programas de Pós-Graduação sobre o tema da saúde e da doença, apresento o quadro abaixo:

Quadro 4. Textos acadêmicos produzidos por pesquisadores pertencentes a segunda geração sobre o tema da História da Saúde e das Doenças da Paraíba.

\begin{tabular}{|c|c|c|c|c|}
\hline & TÍTULO & AUTOR & TIPO & ANO \\
\hline 01 & $\begin{array}{l}\text { Parahyba: uma cidade entre miasmas e } \\
\text { micróbio. O Serviço de Higiene Pública, } \\
1895 \text { a } 1918\end{array}$ & Lenilde Duarte Sá & $\begin{array}{c}\text { Tese } \\
\text { (PIDE/USP) }\end{array}$ & 1999 \\
\hline 02 & $\begin{array}{l}\text { Corpos hígidos: o limpo e o sujo na } \\
\text { Paraíba (1912-1924) }\end{array}$ & $\begin{array}{l}\text { Azemar dos Santos } \\
\text { Soares Júnior }\end{array}$ & $\begin{array}{c}\text { Dissertação } \\
\text { (PPGH/UFPB) }\end{array}$ & 2011 \\
\hline 03 & $\begin{array}{l}\text { As Artes de fazer nascer: do parto } \\
\text { doméstico ao parto hospitalar - o corpo } \\
\text { feminino medicalizado (Campina } \\
\text { Grande, 1950-1970) }\end{array}$ & $\begin{array}{l}\text { Rosineide Alves de } \\
\text { Farias }\end{array}$ & $\begin{array}{c}\text { Dissertação } \\
\text { (PPGH/UFCG) }\end{array}$ & 2012 \\
\hline 04 & $\begin{array}{l}\text { Para a melhoria da raça e a civilização do } \\
\text { povo paraibano: uma história da eugenia } \\
\text { na Paraíba (1914-1921) }\end{array}$ & Júlio César Alves da Silva & $\begin{array}{c}\text { Dissertação } \\
\text { (PPGH/UFPB) }\end{array}$ & 2013 \\
\hline 05 & $\begin{array}{l}\text { A higiene como missão: Fundação } \\
\text { Rockefeller, filantropia e controvérsia } \\
\text { científica Paraíba do Norte (1923-1930) }\end{array}$ & Paloma Porto & $\begin{array}{c}\text { Tese } \\
\text { (PPGH/UFMG) }\end{array}$ & 2014 \\
\hline 06 & $\begin{array}{l}\text { Educação pela higiene: a invenção de um } \\
\text { modelo hígido de educação escolar } \\
\text { primária na Parahyba do Norte (1849- } \\
\text { 1886) }\end{array}$ & $\begin{array}{l}\text { Nayana Rodrigues } \\
\text { Cordeiro Mariano }\end{array}$ & $\begin{array}{c}\text { Tese } \\
\text { (PPGE/UFPB) }\end{array}$ & 2015 \\
\hline 07 & $\begin{array}{l}\text { Physicamente vigorosos: medicalização } \\
\text { escolar e modelação de corpos na Paraíba } \\
(1913-1942)\end{array}$ & $\begin{array}{l}\text { Azemar dos Santos } \\
\text { Soares Júnior }\end{array}$ & $\begin{array}{c}\text { Tese } \\
\text { (PPGE/UFPB) }\end{array}$ & 2015 \\
\hline
\end{tabular}




\begin{tabular}{|c|c|c|c|c|}
\hline 08 & $\begin{array}{l}\text { Entre a ciência e a saúde pública: a } \\
\text { construção do médico paraibano como } \\
\text { reformador social (1911-1929) }\end{array}$ & $\begin{array}{l}\text { Leonardo Q. Barboza } \\
\text { Freire dos Santos }\end{array}$ & $\begin{array}{c}\text { Dissertação } \\
\text { (PPGH/UFCG) }\end{array}$ & 2015 \\
\hline 09 & $\begin{array}{l}\text { Imagens da doença, políticas da notícia: } \\
\text { Cenários e representações da aids na } \\
\text { imprensa paraibana (1980) }\end{array}$ & $\begin{array}{l}\text { Fernando Domingos de } \\
\text { Aguiar Júnior }\end{array}$ & $\begin{array}{c}\text { Dissertação } \\
\text { (PPGH/UFPB) }\end{array}$ & 2016 \\
\hline 10 & $\begin{array}{l}\text { Entre o poder e a ciência: história das } \\
\text { instituições de saúde e de higiene da } \\
\text { Paraíba na Primeira República (1889- } \\
\text { 1930) }\end{array}$ & Silvera Vieira de Araújo & $\begin{array}{c}\text { Tese } \\
\text { (PPGH/UFPE) }\end{array}$ & 2016 \\
\hline 11 & $\begin{array}{l}\text { Doidos[as] e doutores: a medicalização } \\
\text { da loucura na Província/estado da } \\
\text { Parahyba do Norte 1830-1930 }\end{array}$ & $\begin{array}{c}\text { Helmara Giccely F. W. } \\
\text { Junqueira }\end{array}$ & $\begin{array}{c}\text { Tese } \\
\text { (PPGH/UFPE) }\end{array}$ & 2016 \\
\hline 12 & $\begin{array}{l}\text { Os corpos adoecidos: experiências dos } \\
\text { portadores da doença dos "Lábios } \\
\text { Azuis" }\end{array}$ & $\begin{array}{l}\text { Junia de Lima } \\
\text { Nascimento }\end{array}$ & $\begin{array}{c}\text { Dissertação } \\
\text { (PPGH/UFCG) }\end{array}$ & 2017 \\
\hline 13 & $\begin{array}{l}\text { A administração da loucura: a Santa Casa } \\
\text { da Parahyba do Norte no tratamento dos } \\
\text { alienados (1858-1892) }\end{array}$ & Gerlane Farias Alves & $\begin{array}{c}\text { Dissertação } \\
\text { (PPGH/UFPB) }\end{array}$ & 2018 \\
\hline 14 & $\begin{array}{l}\text { "Cultura physica para a família } \\
\text { campinense": higiene e educação física } \\
\text { no Instituto Pedagógico - Campina } \\
\text { Grande (1931-1942) }\end{array}$ & Alexandro dos Santos & $\begin{array}{c}\text { Dissertação } \\
\text { (PPGH/UFCG) }\end{array}$ & 2018 \\
\hline 15 & $\begin{array}{l}\text { O médico disse que estou magrinho?: } \\
\text { alimentação na infância como uma } \\
\text { prática educativa na Paraíba (1918 a } \\
\text { 1937) }\end{array}$ & $\begin{array}{c}\text { Marinalva Bezerra Vilar } \\
\text { de Carvalho }\end{array}$ & $\begin{array}{c}\text { Dissertação } \\
\text { (PPGH/UFCG) }\end{array}$ & 2018 \\
\hline 16 & $\begin{array}{l}\text { A lymfoterapia ou a cura pelo cuspe: os } \\
\text { saberes "médicos" produzidos pelo } \\
\text { curandeiro/farmacêutico José Fábio Lyra } \\
\text { na Paraiba (1904-1945) }\end{array}$ & $\begin{array}{c}\text { Rosana do Nascimento } \\
/ \mid \text { Gomes Melo } \|\end{array}$ & $\begin{array}{c}\text { Dissertação } \\
\text { (PPGH/UFCG) }\end{array}$ & 2019 \\
\hline 17 & $\begin{array}{l}\text { "A lepra e a ordem": uma história da } \\
\text { construção do Hospital Colônia Getúlio } \\
\text { Vargas - Paraíba (1929-1941) }\end{array}$ & $\begin{array}{l}\text { Emanoel Calixto do } \\
\text { Nascimento }\end{array}$ & $\begin{array}{c}\text { Dissertação } \\
\text { (PPGH/UFPB) }\end{array}$ & 2019 \\
\hline 18 & $\begin{array}{l}\text { Santa Casa dos mortos: ritos fúnebres, } \\
\text { mortalidade e relações de poder na } \\
\text { Paraíba oitocentista }\end{array}$ & Nereida Soares Martins & $\begin{array}{c}\text { Tese } \\
\text { (PPGH/UFPE) }\end{array}$ & 2019 \\
\hline 19 & $\begin{array}{l}\text { O terrível flagelo da humanidade: os } \\
\text { discursos médico-higienistas no combate } \\
\text { à sífilis na Paraíba (1921-1940) }\end{array}$ & Rafael Nóbrega Araújo & $\begin{array}{c}\text { Dissertação } \\
\text { (PPGH/UFCG) }\end{array}$ & 2020 \\
\hline 20 & $\begin{array}{l}\text { Admirável corpo novo: discursos } \\
\text { médicos sobre as classes trabalhadoras } \\
\text { (Paraíba, 1930-1945) }\end{array}$ & $\begin{array}{l}\text { Leonardo Q. Barboza } \\
\text { Freire dos Santos }\end{array}$ & $\begin{array}{c}\text { Tese } \\
(\mathrm{PPGH} / \mathrm{USP})\end{array}$ & 2020 \\
\hline 21 & $\begin{array}{l}\text { Artes de Curar em Confronto? Disputas, } \\
\text { Ofícios e Práticas de cura na Paraíba } \\
\text { Imperial (1870-1880) }\end{array}$ & $\begin{array}{l}\text { Wuendisy Fortunato da } \\
\text { Silva }\end{array}$ & $\begin{array}{c}\text { Dissertação } \\
\text { (PPGH/UFPB) }\end{array}$ & 2020 \\
\hline
\end{tabular}

Fonte: Quadro elaborado pelo autor a partir dos dados coletados no banco de dissertação e teses da Capes (2021).

Como consta no detalhamento do quadro acima, foi possível identificar vinte e um trabalhos acadêmicos produzidos sobre a história da saúde e das doenças na Paraíba, sendo treze dissertações de mestrado e oito teses de doutoramento. Algumas dessas teses foram escritas em Programas de Pós-Graduação fora da geografia paraibana, a exemplo dos 
trabalhos de Lenilde Sá (1999) na Escola de Enfermagem da USP, Paloma Porto (2014) no Programa de História da UFMG, Silvera Araújo (2016), Helmara Junqueira (2016) e Nereida Martins (2019) no Programa de Pós-Graduação em História da UFPE e Leonardo Santos (2020) no Programa de Pós-Graduação em História da USP. As outras duas teses no campo - Nayana Mariano (2015) e Azemar Soares Jr. (2015) -, foram defendidas no Programa de Pós-Graduação em Educação da UFPB. Quanto às dissertações arquitetadas sobre os temas que compõem o campo, todas foram defendidas nos Programas de PósGraduação em História da UFPB (seis dissertações) e da UFCG (sete dissertações).?

No que diz respeito aos temas, foi possível através da leitura dos resumos desses trabalhos classificar aspectos que considero importante como temas, temporalidades e dominio teórico. Quanto ao tema, foi possível identificar quatro trabalhos sobre História das Doenças: Helmara Junqueira (2016), Fernando Aguiar Jr. (2016), Junia Nascimento (2017) e Rafael Nóbrega (2020); História da Higiene e da Educaşão Sanitária: Lenilde Sá (1999), Azemar Soares Jr. (2011), Júlio Silva (2013), Nayana Mariano (2015), Azemar Soares Jr. (2015), Silvera Araújo (2016), Alexandro dos Santos (2018) e Marinalva Carvalho (2018); quando o assunto é Instituição Médica, destacam-se os trabalhos de Paloma Porto (2014), Gerlane Alves (2018), Emanoel Calixto (2019) e Nereida Martins (2019); com o tema Saberes Médicos, cito Rosineide Farias (2012), Leonardo Santos (2015) e Leonardo Santos (2020); e sobre Práticas de Cura, as dissertações de Rosana Nascimento (2019) e Wuendisy Silva (2020). Dessa forma, a maior parte dos trabalhos produzidos estão relacionados ao tema da História da Higiene e da Educaşão Sanitária com oito pesquisas, seguidos de História das Doenças e as Instituições Médicas, possuindo cada um quatro pesquisas finalizadas, Saberes Médicos com três trabalhos defendidos e Práticas e Cura com dois.

Quanto à temporalidade das pesquisas realizadas, nenhuma delas contempla o Período Colonial. Quatro trabalhos se classificam exclusivamente como oitocentistas, ou seja, toda a temporalidade analisada está compreendida no século XIX. Outros três textos estão temporalmente no período que chamamos de transição do Império para a República, do oitocentos para o novecentos. Porém, a grande maioria das pesquisas desenvolvidas foram sobre o vigésimo século, totalizando quatorze produções acadêmicas. Nesse leque aberto ao novecentos, faz-se importante destacar que onze escritos estão cronologicamente localizados na primeira metade do vigésimo século, e apenas três na segunda metade.

9credito ser importante registrar que a maioria dessas dissertações defendidas nos Programas de PósGraduação em História da UFPB e UFCG, foram orientadas pelos professores Iranilson Buriti de Oliveira (UFCG), Serioja Mariano (UFPB) e Azemar Soares Júnior (UFCG). Esses pesquisadores também se dedicam ao desenvolvimento de pesquisas no campo da história da saúde e das doenças, publicando artigos e livros. 
Dentre os aspectos teóricos, a História Cultural aparece quase que de forma majoritária, sendo apontada enquanto domínio de dezessete pesquisas, enquanto a História Social é anunciada em outras quatro.

Esses estudos da história da saúde e das doenças na Paraíba formaram aquilo que estou chamando de uma segunda geração de historiadores desse campo. São profissionais historiadores que viram diante de si a possibilidade de tratar o tema da saúde e da doença graças ao "alargamento da agenda histórica e de áreas florescentes [...] englobando as doenças crônicas, endêmicas e epidêmicas, as implicações sociais, políticas e ecológicas [...] os entendimentos sobre doença e seus cuidados em diferentes contextos sociais, ponto de vista do paciente, os instrumentos de controle médico-social" (NASCIMENTO, SILVEIRA, 2004, p. 13). Os estudos sobre o tema da saúde são uma realidade, especialmente fora do Brasil, desde meados do século XX. Porém, o campo ganhou força com as pesquisas de Sérgio Carrara, com seu Tributo a vênus (1996), dedicado ao entendimento da sífilis e da luta antivenérea, e à pesquisa comparativa entre tuberculose e aids realizada por Dilene Nascimento, e batizada como Da diferença do poder a uma vida diferente: tuberculose e aids no Brasil (1999). Além desses, outros trabalhos começaram a se firmar no campo da história das doenças, buscando problematizar as representações sociais articuladas aos estudos sobre as epidemias, recheadas de "uma gama de abordagens e fenômenos patológicos" (NASCIMENTO, SILVEIRA, 2004, p. 24). Os esforços desses pesquisadores ganharam ânimo Brasil afora incentivando a investidura em pesquisas no campo da História da Saúde e das Doenças. Os esforços desses pesquisadores ganharam ânimo Brasil afora incentivando a investidura em pesquisas no campo da História da Saúde e das Doenças, e, na Paraíba, gestando pesquisas sobre histórias de doenças, das epidemias e endemias, das artes de curar, dos discursos médico-higiênicos, da educação sanitária, dos profissionais da saúde e das instituições médicas.

\section{CONSIDERAÇÕES FINAIS}

Não é prudente afirmar que nesse texto demos conta de elencar e classificar todos os autores e obras que foram produzidas no campo da História da Saúde e das Doenças na Paraíba. É possível que algum texto tenha ficado de fora, seja pela falta de conhecimento, ou mesmo pela dificuldade de acesso.

Reafirmo que esse artigo se trata de uma tentativa de classificar a historiografia do tema através do recurso teórico-metodológico de geração, proposto por Sirinelli (2001). Nesse sentido, identificamos a existência de duas gerações, sendo a primeira composta por 
não historiadores vinculados às sociedades do saber que acreditavam que a transcrição documental se configurava enquanto uma verdade absoluta, ou mesmo usava de informações vistas no cotidiano da época para realizar denúncias políticas; enquanto a segunda é filha dileta das pesquisas nos programas de pós-graduação e do avanço do campo da história da saúde e das doenças no Brasil.

Na Paraíba, é possível afirmar que a história da saúde e das doenças é um campo em construção, e ousaria dizer, promissor. Não existe um grupo de trabalho ou grupo de pesquisa dedicado ao campo nessa geografia. Recentemente, com a realização do I Seminário de História da Saúde e das Doenças no Nordeste do Brasil, foram apresentados diversos trabalhos desenvolvidos por pesquisadores paraibanos sobre o tema, revelando assim a necessidade de uma organização institucional que possa reunir esses estudiosos e alargar as possibilidades de pesquisas que considero importantes para entender a desorganização e reorganização dos espaços, dos corpos, da vida.

\section{REFERÊNCIAS}

AGUIAR JR., F. D. Imagens da doença, políticas da notícia: Cenários e representações da aids na imprensa paraibana (1980). Dissertação (Mestrado em História). Programa de Pós-Graduação em História, Universidade Federal da Paraíba, 2016.

AGUIAR, W. A velha Paraíba nas páginas de jornais. João Pessoa: A União, 1999. ALMEIDA, J. A. A Paraíba e seus problemas. João Pessoa: A União, 1980.

ALVES, G. F. A administração da loucura: a Santa Casa da Parahyba do Norte no tratamento dos alienados (1858-1892). Dissertação (Mestrado em História). Programa de Pós-Graduação em História, Universidade Federal da Paraíba, 2018.

ARAÚJO, R. N. O terrível flagelo da humanidade: os discursos médico-higienistas no combate a sífilis na Paraíba (1921-1940). Dissertação (Mestrado em História). Programa de Pós-Graduação em História, Universidade Federal de Campina Grande, 2020.

ARAÚJO, S. V. Entre o poder e a ciência: história das instituições de saúde e de higiene da Paraíba na Primeira República (1889-1930). Tese (Doutorado em História). Programa de Pós-Graduação em História, Universidade Federal de Pernambuco, 2016.

CARVALHO, M. B. V. O médico disse que estou magrinho?: alimentação na infância como uma prática educativa na Paraíba (1918 a 1937). Dissertação (Mestrado em História). Programa de Pós-Graduação em História, Universidade Federal de Campina Grande, 2018. CASTRO, O. O. Medicina na Paraíba. João Pessoa: A União, 1945.

CASTRO, O. O. Subsídios a história da medicina na Parahyba: corrida de diagnósticos. Revista Medicina, n. 1, 1936, p. 24-29. 
CASTRO, O. O. Subsídios a história da medicina na Parahyba: o caso Thomaz Camboia. Revista Medicina, n. 2 e 3, 1936, p. 93-99.

CASTRO, O. O. Subsídios a história da medicina na Parahyba: um caso esporádico. Revista Medicina, n. 4, 1937, p. 35-40.

COELHO FILHO, H. A epidemia de cólera morbo na Paraíba em 1856. Revista Medicina, n. 19 e 20, 1959, p. 29-34.

COELHO FILHO, H. Medicina, doenças e médicos nos primeiros anos da Paraíba. Revista do IHGP, n. 18, 1971, p. 177-195.

FARIAS, R. A. As artes de fazer nascer: do parto doméstico ao parto hospitalar - o corpo feminino medicalizado (Campina Grande, 1950-1970). Dissertação (Mestrado em História). Programa de Pós-Graduação em História, Universidade Federal de Campina Grande, 2012.

GALVÍNCIO, A. S. A trajetória intelectual de Eudésia Vieira: educação, feminismos e história pátria (1921-1955). Tese (Doutorado em Educação). Programa de Pós-Graduação em Educação, Centro de Educação, Universidade Federal da Paraíba, 2019.

JUNQUEIRA, H. G. F. W. Doidos[as] e doutores: a medicalização da loucura na Província/estado da Parahyba do Norte 1830-1930. Tese (Doutorado em História). Programa de Pós-Graduação em História, Universidade Federal de Pernambuco, 2016.

MARIANO, N. R. C. Educação pela higiene: a invenção de um modelo hígido de educação escolar primária na Parahyba do Norte (1849-1886). Tese (Doutorado em Educação). Programa de Pós-Graduação em Educação, Universidade Federal da Paraíba, 2015.

MAROJA, F. Nossa hygiene. Revista do Instituto Histórico e Geográfico da Paraíba, João Pessoa, n.03, p. 431-437, 1911.

MARTINS, N. S. Santa Casa dos mortos: ritos fúnebres, mortalidade e relações de poder na Paraíba oitocentista. Tese (Doutorado em História). Programa de Pós-Graduação em História, Universidade Federal de Pernambuco, 2019.

MEDEIROS, C. Subsidio para a história da hygiene pública na Parahyba. Revista do Instituto Histórico e Geográfico da Paraíba, n. 3, 1911, p. 117-124.

MEDEIROS, J. E. M, LUCAS, J. M. Dicionário Biográfico dos Médicos da Paraíba. João Pessoa: Grafique, 2014.

MELO, R. N. G. A lymfoterapia ou a cura pelo cuspe: os saberes "médicos" produzidos pelo curandeiro/farmacêutico José Fábio Lyra na Paraíba (1904-1945). Dissertação (Mestrado em História). Programa de Pós-Graduação em História, Universidade Federal de Campina Grande, 2019.

NASCIMENTO, J. L. Os corpos adoecidos: experiências dos portadores da doença dos "Lábios Azuis". Dissertação (Mestrado em História). Programa de Pós-Graduação em História, Universidade Federal de Campina Grande, 2017. 
NASCIMENTO, E. C. “A lepra e a ordem”: uma história da construção do Hospital Colônia Getúlio Vargas - Paraíba (1929-1941). Dissertação (Mestrado em História). Programa de Pós-Graduação em História, Universidade Federal da Paraíba, 2019.

NÓBREGA, H. As raízes das ciências da saúde na Paraíba. João Pessoa: UFPB, 1979. PINHEIRO, A. C. F. Historiadores da educação brasileira: gerações em diálogos. Revista Brasileira de História da Educação, v. 19, 2019, p. 1-26.

PINTO, I. O cholera-morbus na Paraíba. Revista do IHGP, n. 2, 1910, p. 117-132.

PORTO, P. A higiene como missão: Fundação Rockefeller, filantropia e controvérsia científica Paraíba do Norte (1923-1930). Tese (Doutorado em História). Programa de PósGraduação em História, Universidade Federal de Minas Gerais.

REIS, J. C. História: entre a filosofia e a ciência. Belo Horizonte: Autêntica, 1999.

SÁ, L. D. Parahyba: uma cidade entre miasmas e micróbios. O Serviço de Hygiene Pública, 1895 a 1918. Tese (Doutorado em Enfermagem), Escola de Enfermagem de Ribeirão Preto, Universidade de São Paulo, 1999.

SANTOS, A. “Cultura physica para a família campinense”: higiene e educação física no Instituto Pedagógico - Campina Grande (1931-1942). Dissertação (Mestrado em História). Programa de Pós-Graduação em História, Universidade Federal de Campina Grande, 2018.

SANTOS, L. Q. B. F. Entre a ciência e a saúde pública: a construção do médico paraibano como reformador social (1911-1929). Dissertação (Mestrado em História). Programa de Pós-Graduação em História, Universidade Federal de Campina Grande, 2015.

SANTOS, L. Q. B. F. Admirável corpo novo: discursos médicos sobre as classes trabalhadoras (Paraíba, 1930-1945). Tese (Doutorado em História Social). Programa de Pós-Graduação em História, Universidade de São Paulo, 2020.

SILVA, B. B. S. O poder político de José Américo de Almeida: a construção do americismo (1928-1935). Dissertação (Mestrado em História). Programa de Pós-Graduação em História, Universidade Federal da Paraíba, 2015.

SILVA, J. C. A. Para a melhoria da raça e a civilização do povo paraibano: uma história da eugenia na Paraíba (1914-1921). Dissertação (Mestrado em História). Programa de Pós-Graduação em História, Universidade Federal da Paraíba, 2013.

SILVA, W. F. Artes de Curar em Confronto? Disputas, Ofícios e Práticas de cura na Paraíba Imperial (1870-1880). Dissertação (Mestrado em História). Programa de PósGraduação em História, Universidade Federal da Paraíba, 2020.

SILVEIRA, A, J. T.; NASCIMENTO, D. R. A doença revelando a história. Uma historiografia das doenças. In: CARVALHO, D. M.; NASCIMENTO, D. R. Uma história brasileira das doenças. Brasília: Paralelo 15, 2004, p. 13-30.

SIRINELLI, J. F. A geração. In: AMADO, J.; FERREIRA, M. M. Usos \& abusos da história oral. Rio de Janeiro: FGV, 2001, p. 131-137. 
SOARES JR. A. S. Corpos hígidos: o limpo e o sujo na Paraíba. Dissertação (Mestrado em História). Programa de Pós-Graduação em História, Universidade Federal da Paraíba, 2011.

SOARES JR. A. S. Physicamente vigorosos: medicalização escolar e modelação de corpos na Paraíba (1913-1942). Tese (Doutorado em Educação). Programa de PósGraduação em Educação, Universidade Federal da Paraíba, 2015.

SOCIEDADE DE MEDICINA E CIRURGIA DA PARAÍBA. Semana médica. Parahyba: Imprensa Oficial, 1927.

VIDERES, A. R. N, NÓBREGA, M. M. L. Lenilde Duarte de Sá: vida e docência inspiradas na arte do cuidar. História Enfermagem Revista Eletrônica, n. 9, v. 2, 2018, p. $141-148$.

RECEBIDO EM: 13/09/2021 PARECER DADO EM: 25/10/2021 